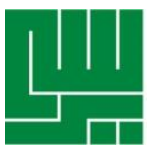

KATA KUNCI

KEYWORDS

ABSTRAK

ABSTRACT

\section{Modifikasi, Validitas, dan Reliabiltas Alat Ukur Pemikiran Karier Untuk Remaja}

\section{Modification, Validity and Reliability Testing of Career Thought Inventory for Adolescent}

\author{
Lucky Wibowo $^{1} \&$ William Gunawan ${ }^{2}$ \\ Fakultas Psikologi Universitas Kristen Krida Wacana \\ Jl. Tanjung Duren Raya No. 4 Jakarta 11470 \\ Email: Lucky.Wibowo014@gmail.com; william.gunawan@ukrida.ac.id
}

inventori pemikiran karier, pemrosesan informasi kognitif, remaja

career thought inventory, cognitive information processing, adolescent

Berdasarkan pendekatan pemrosesan informasi kognitif, ada tiga komponen dasar yang mempengaruhi pengambilan keputusan karier seseorang, antara lain knowledge domain, decision making skills domain, dan executive processing domain. Ketiga komponen ini digunakan untuk mengenali kesalahan berpikir dalam pengambilan keputusan karier, dan dioperasionalisasikan alat ukur inventori pemikiran karier. Tujuan penelitian ini adalah untuk memodifikasi dan menguji validitas dan reliabilitas inventori pemikiran karier. Penelitian sebelumnya menunjukkan bahwa alat ukur ini valifd dan reliabel tetapi memiliki beberapa kelemahan dalam penyususnan item. Penelitian ini adalah penelitian kuantitatif non-eksperimen dengan menggunakan sampel 462 remaja. Hasil penelitian menunjukkan 42 dari 48 item alat ukur valid dan reliabel untuk remaja usia 15-21 tahun. Penelitian selanjunya dibutuhkan untuk menentukan norma alat ukur inventori pemikiran karier.

There were three basic component that influence someone's career deision making, based on cognitive information procesiing approach, namely knowledge domain, decision making skills domain and executi processing domain. This three componen was used to identify false thinking in career decision making operationalized by career thought inventory. The pupose of this study was to mofified, and test the validity and reliability of career thought inventory (CTI). Previous research showed that this scale was is valid and reliable but showed some weakness in item. Using a non-experimental quantitative research with cronbach's alpha analysis, 462 adolesence was used. The result showed 42 item from accumulative total 48 item stated valid and reliable for adolescence age 15-21 years old. Further research needed to standardize the norm of career thought inventory. 


\section{PENDAHULUAN}

Karier merupakan salah satu aspek penting dalam kebahagiaan hidup (Sharf, 2006). Secara lebih luas, karier berbicara mengenai proses yang berlangsung terus menerus sepanjang kehidupan kita. Pentingnya karier sebagai salah satu aspek penting dalam kebahagiaan hidup, menjadikan persiapan dan perencanaan karier sejak dini merupakan hal yang penting.

Ada berbagai pendekatan dalam pengambilan keputusan karier, antara lain dari pandangan spiritual, kepribadian, pemerosesan informasi kognitif, dan sebagainya. Dalam penelitian ini, peneliti menggunakan pendekatan pemerosesan informasi kognitif. Hal ini dikarenakan pendekatan pemerosesan informasi kognitif merupakan teori yang cukup baru, sehingga dirasa sesuai dengan kondisi di Indonesia yang cepat berubah. Pendekatan pemerosesan informasi kognitif dari Peterson (dalam Sharf, 2006), berfokus pada emosi dan pemerosesan informasi kognitif yang dianggap sebagai komponen penting dalam pengambilan keputusan karier.Dalam hal ini, emosi yang dimaksud berupa kecemasan, kebingungan, maupun depresi. Sedangkan dari segi pemerosesan informasi kognitif, ada tiga komponen dasar yang mempengaruhi pengambilan keputusan karier seseorang, antara lain knowledge domain, decision making skills domain, dan executive processing domain.

Berdasarkan pendekatan pemerosesan informasi kognitif, Peterson (dalam Sharf, 2006) mengklasifikasikan individu dalam tiga kelompok besar, yakni memutuskan, tidak memutuskan, raguragu.Seseorang yang mampu mengambil keputusan memiliki kemungkinan untuk menutupi bahwa sebenarnya mereka tidak dapat memutuskan.Untuk orang-orang yang tidak dapat memutuskan mungkin membutuhkan informasi lebih untuk mengambil keputusan, ada juga yang disebabkan kurangnya mengenal diri dan informasi pekerjaan, dan sisanya dikarenakan banyaknya talenta dan minat yang dimiliki.Orang yang ragu-ragu adalah mereka yang memiliki pendekatan yang salah dalam mengambil keputusan, secara umum hal ini disebabkan karena adanya kecemasan.

Dari teori pendekatan pemerosesan informasi kognitif, berkembang suatu alat test untuk membantu memetakan individu ke dalam tiga kategori besar dan memahami pemerosesan informasi kognitif yang terjadi, salah satunya adalah inventori pemikiran karier (IPK). IPK salah satu alat test yang membantu seseorang untuk mengetahui pemikiran disfungsional. IPK terdiri dari 48 item yang di bagi ke dalam 3 skala besar, yakni kebingungan mengambil keputusan/ decision making confusion (DMC) mengindikasi kesulitan individu dalam membuat keputusan, konflik eksternal/ external conflict (EC) mengindikasi kesulitan individu dalam mengimbangi informasi dari luar dan dari dalam dirinya, dan kecemasan berkomitmen/ commitment anxiety (CA) dikarenakan ketakutan dan kecemasan seseorang yang diikuti dengan kesulitan untuk melaksanakan pilihan karier. Untuk pemberian respon, IPK memiliki 4 pilihan respon, yakni Sangat Tidak Setuju "STS"; Tidak Setuju "TS"; Setuju "S"; dan Sangat Setuju "SS". IPK dapat digunakan pada rentang usia 17-83 tahun dengan estimasi pengerjaan selama kurang lebih 7 menit sampai 15 menit.

Menurut Sharf (2006), untuk dapat digunakan suatu tes atau inventori haruslah sesuai dengan norma, valid dan reliabel. Berdasarkan penelitian yang dilakukan oleh Pratomo (2012), 46 item dari 48 item yang ada di IPK telah dinyatakan valid dan reliabel di Indonesia dengan nilai rentang nilai validitas 0,310-0,570 dan dengan rentang nilai reliabilitas 0,910-0,905 setelah dilakukan eliminasi pada item yang tidak valid. Dengan demikian, IPK dapat digunakan di Indonesia untuk rentang usia 17-24 tahun.

Sebagai suatu alat tes, peneliti melihat kelemahan dari terjemahan IPK yang telah dilakukan oleh Pratomo (2012). 
Kelemahan tersebut, terletak pada aitem yang mengandung dua gagasan dalam satu aitem. Beberapa contoh aitem tersebut adalah "tidak ada bidang studi atau pekerjaan yang menarik bagi saya"; "saya gundah saat memilih bidang studi atau pekerjaan, sehingga saya tidak dapat memulainya"; "saya tidak dapat memikirkan bidang studi atau pekerjaan apa saja yang sesuai dengan saya”.

Menurut Osterlind (2002), untuk menjadi aitem alat test yang baik perlu memenuhi beberapa kriteria, yakni salah satu kriteria aitem yang baik adalah satu aitem memiliki satu gagasan. Pentingnya suatu aitem untuk dikatakan baik, karena aitem memiliki pengaruh kepada validitas dan reliabilitas suatu tes. Jika suatu aitem tersebut baik, maka validitas dan reliabilitas yang didapatkan akan tinggi.

Selain kelemahan dari segi aitem yang telah disebutkan di atas, peneliti juga melihat adanya kekurangan penelitian dari segi uji validitas dan reliabilitas yang dilakukan Pratomo (2012). Peneliti menemukan bahwa nilai validitas dan reliabilitas yang dilakukan oleh Pratomo (2012) bukanlah nilai validitas dan reliabilitas total, melainkan nilai validitas dan reliabilitas perdimensi dari IPK.

Melihat kelemahan dari IPK sebagai suatu alat test serta kurangnya perhitungan pada penelitian sebelumnya, membuat peneliti tertarik untuk melakukan modifikasi pada aitem-aitem IPK sesuai dengan kebutuhan dan melakukan uji validitas dan reliabilitas ulang mengenai IPK untuk remaja usia 15-21 tahun.

\section{Pengambilan Keputusan Karier}

Berdasarkan pendekatan pemerosesan informasi kognitif (Sharf, 2006), pengambilan keputusan karier merupakan hasil proses kognitif dan dan afektif. Pendekatan ini berfokus pada bagaimana membantu seseorang memahami apa yang dipikirkan mereka dan bagaimana pemikiran itu mempengaruhi pengambilan keputusan karier mereka. Jadi, pengambilan keputusan karier merupakan hasil dari proses kognitif yang meliputi pemahaman akan diri sendiri, pengetahuan dunia kerja, proses analisa, sintesis, dan pengambilan keputusan.

\section{Pemerosesan Informasi Kognitif}

Sharf (2006), pendekatan ini berfokus pada bagaimana individu berpikir mengenai karier mereka dan bagaimana pemikiran mereka berpengaruh terhadap pengambilan keputusan karier mereka. dalam pemerosesan informasi kognitif terdapat tiga komponen dasar, antara lain (1) domain pengetahuan; (2) domain kemampuan pengambilan keputusan; (3) domain proses memutuskan. Proses berpikir ini dapat dilihat pada gambar 1 .

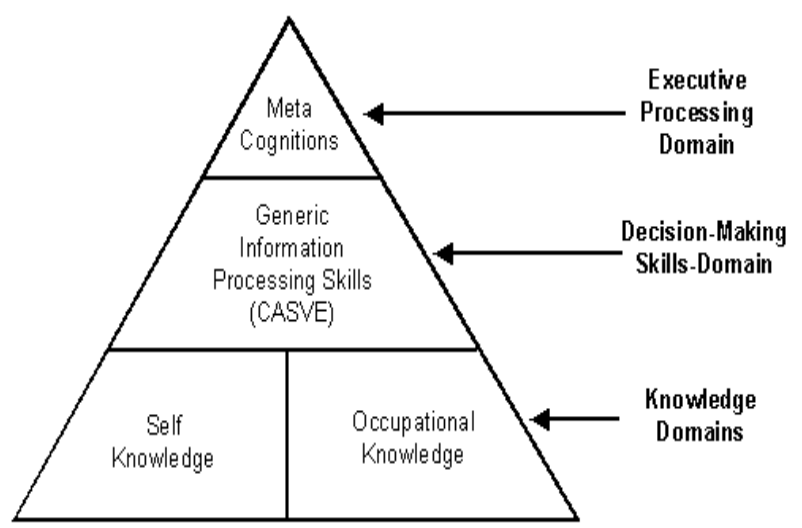

Gambar 1. Piramida pemerosesan informasi kognitif

Domain pengetahuan, terdiri dari pengetahuan mengenai diri (minat, tes kemampuan, nilai di sekolah) dan pengetahuan mengenai pekerjaan meliputi berbagai informasi penting seperti pendidikan, ataupun lapangan kerja. Domain kemampuan pengambilan keputusan, domain ini meliputi berbagai proses, antara lain komunikasi, analisia, sintesa, penilaian, dan memutuskan (CASVE). Domain terakhir adalah domain proses memutuskan. Domain ini terdiri dari self-talk, self-awareness, dan pengawasan dan kontrol.

Proses pengambilan keputusan karier dengan menggunakan pendekatan CASVE dapat dilihat pada gambar 2 . 


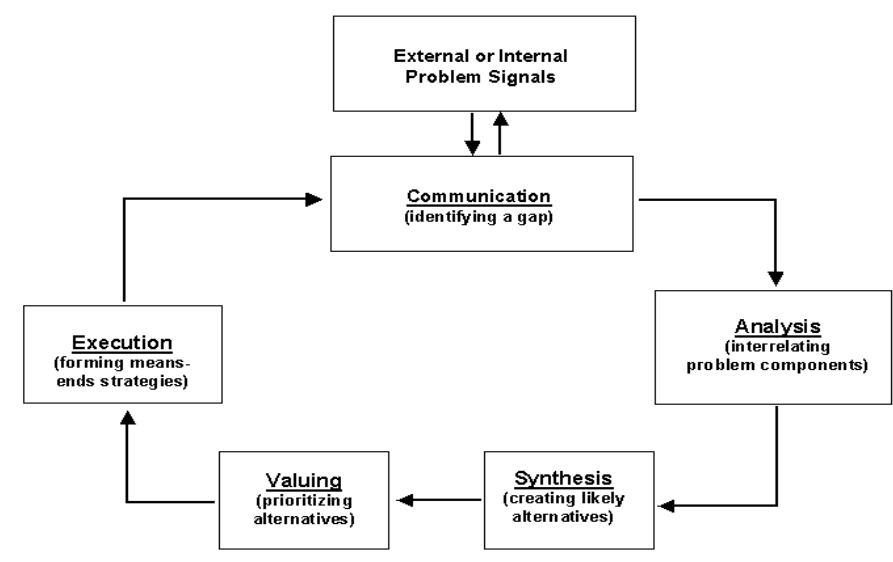

Gambar 2. Lingkaran CASVE

\section{Inventori Pemikiran Karier}

Sampson, Peterson, Lenz, Reardon, dan Saunders (1996) IPK merupakan alat tes psikologi yang membantu individu mengidentifikasi pemikiran mereka yang disfungsional yang mengganggu mereka dalam menyelesaikan masalah karier dan mengambil keputusan karier (Amelia \& Gunawan, 2014). Secara khusus, IPK dapat digunakan sebagai instrument untuk penyaringan dan mengukur kebutuhan, serta dapat juga digunakan untuk sumber pembelajaran bagi pelayanan karier.

IPK terdiri dari 48 aitem pernyataan yang berisi pernyataan negatif dan terbagi dari 3 skala konstruk Skala konstruk tersebut, antara lain (1) kebingungan pengambilan keputusan; (2) kecemasan berkomitmen; (3) konflik eksternal

Ketiga skala konstruk tersebut tersebar dalam aitem-aitem IPK yang dijabarkan dalam table 1 . Selain itu, aitemaitem tersebut juga dapat dikelompokkan berdasarkan domain dan dimensi pemrosesan informasi kognitif yang dapat dilihat pada tabel 2.

Tabel 1. Skala konstruk dalam aitem-aitem CTI

\begin{tabular}{ll}
\hline \multicolumn{1}{c}{ Skala Konstruk } & \multicolumn{1}{c}{ No. Item } \\
\hline Kebingungan pengambilan keputusan & $1,3,4,5,11,12,13,16,20,27,28,36,43$, \\
& 44 \\
Kecemasan berkomitmen & $17,21,22,26,29,30,32,35,38,47$ \\
Konflik eksternal & $6,9,14,23,46$ \\
\hline
\end{tabular}

Tabel 2. Dimensi PIK dalam aitem-aitem IPK

\begin{tabular}{lc}
\hline \multicolumn{1}{c}{ Dimensi } & \multicolumn{1}{c}{ No. Item } \\
\hline Pengetahuan diri (SK) & $1,9,17,25,33,41$ \\
Pengetahuan pekerjaan (OK) & $2,10,18,26,34,42$ \\
Komunikasi (C) & $3,11,19,27,35,43$ \\
Analisa (A) & $4,12,20,28,36,44$ \\
Sintesa (S) & $5,13,21,29,37,45$ \\
Penilaian (V) & $6,14,22,30,38,46$ \\
Memutuskan (E) & $7,15,23,31,39,47$ \\
Pemerosesan memutuskan (EP) & $8,16,24,32,40,48$ \\
\hline
\end{tabular}

Dalam pengerjaannya, IPK memiliki 4 pilihan skala dari sangat tidak setuju sampai sangat setuju.IPK dapat diadministrasikan secara individual maupun kelompok selama 7 sampai 15 menit dan dapat dinilai selama 5-8 menit.

Total skor IPK meliputi 48 aitem yang ada dan sekaligus menjadi indikator global dari pemikiran disfungsional dalam pemecahan masalah karier dan pengambilan keputusan. Semakin rendahnya skor total, maka semakin rendahnya pemikiran disfungsional tentang karier.Sedangkan, semakin tingginya skor total, maka pemikiran disfungsional semakin besar.

Adapun contoh aitem dari CTI yang telah direvisi oleh peneliti, antara lain "tidak ada jurusan perkuliahan yang menarik bagi saya"; "informasi mengenai jurusan perkuliahan cenderung memberikan kesan bahwa jurusan 
perkuliahan tersebut bagus"; dan "saya gundah saat memilih jurusan perkuliahan, sehingga saya tidak dapat memulainya.

\section{METODE PENELITIAN}

Penelitian ini merupakan penelitian kuantitatif non-eksperimental. Analisa dalam penelitian ini menggunakan cronbach's alpha. Sarwono (2012), menyatakan stadar suatu aitem untuk dikatakan valid adalah 0,24 dan nilai standar untuk reliabilitas adalah 0,80.
Penelitian ini melibatkan 462 remaja yang berada di rentang usia 15-21 tahun dan berada di jenjang pendidikan SMA di wilayah Jakarta dan Tangerang.Dalam penelitian ini, pengambilan sampel dilakukan dengan teknik purposive sampling. Dalam pengambilan sampel, peneliti bekerja sama dengan Pusat Layanan Psikologi Universitas Kristen Krida Wacana (UKRIDA) dalam kegiatan intervensi karier berupa ceramah, psikotes dan konseling yang diberi nama kegiatan Sukses Setelah Sekolah (3S). Berikut gambaran subjek dalam penelitan ini:

Tabel 3. Gambaran Subjek Penelitian

\begin{tabular}{lll}
\hline Kategori & Jumlah (orang) & Presentase (\%) \\
\hline Jenis kelamin & & \\
- Pria & 193 & 41,77 \\
- Wanita & 269 & 58,23 \\
Usia (tahun) & & \\
- $\quad 15-16$ & 38 & 12,55 \\
- $17-18$ & 11 & 85,06 \\
- 19-21 & & 2,38 \\
Asal sekolah & 72 & \\
- SMA Al-Huda & 91 & 15,58 \\
- SMA PSKD4 & 30 & 19,70 \\
- SMAN 2 Tangerang & 215 & 6,49 \\
- SMAN 56 & 54 & 46,54 \\
- Sekolah lain & & 11,68 \\
Berdasarkan IPK & 4 & \\
- 0-27 (tidak bermasalah) & 15 & 0,86 \\
- 28-47 (sedikit bermasalah) & 189 & 3,25 \\
- 48-68 (cukup bermasalah) & 204 & 41 \\
- 69-88 (bermasalah) & 50 & 10,82 \\
- 89-144 (sangat bermasalah) & 50 & \\
\hline
\end{tabular}

Alat pengumpul data menggunakan alat tes IPK yang terdiri dari 48 aitem dengan empat pilihan respon "STS" untuk sangat tidak setuju sampai "SS" untuk sangat setuju. Untuk pengaplikasia alat test ini membutuhakan waktu kurang lebih 715 menit. Nilai validitas dari alat tes IPK berkisar antara $0,310-0,570$ dan nilai reliabilitas sebesar 0,905-0,910. 
ANALISIS \& HASIL

Pengujian validitas dan reliabilitas dilakukan berdasarkan masing-masing dimensi. Berdasarkan pengujian validitas

dan reliabilitas dari tes IPK didapatkan hasil sebagai berikut:

\section{Validitas dan Reliabilitas Dimensi Kebingungan Pengambilan Keputusan Karier}

Tabel 4. Hasil pengujian validitas dan reliabilitas dimensi kebingungan pengambilan keputusan

\begin{tabular}{cccc}
\hline No aitem & Nilai Validitas & Nilai Reliabilitas & Keterangan \\
\hline 1 & 0,368 & 0,828 & Aitem valid dan reliable \\
3 & 0,449 & 0,823 & Aitem valid dan reliable \\
4 & 0,543 & 0,816 & Aitem valid dan reliable \\
5 & 0,574 & 0,814 & Aitem valid dan reliable \\
11 & 0,376 & 0,827 & Aitem valid dan reliable \\
12 & 0,558 & 0,815 & Aitem valid dan reliable \\
13 & 0,425 & 0,824 & Aitem valid dan reliable \\
16 & 0,437 & 0,824 & Aitem valid dan reliable \\
20 & 0,552 & 0,816 & Aitem valid dan reliable \\
27 & 0,449 & 0,820 & Aitem valid dan reliable \\
28 & 0,445 & 0,823 & Aitem valid dan reliable \\
36 & 0,445 & 0,823 & Aitem valid dan reliable \\
43 & 0,335 & 0,831 & Aitem valid dan reliable \\
44 & 0,485 & 0,820 & Aitem valid dan reliable \\
\hline
\end{tabular}

Berdasarkan tabel di atas, bahwa nilai validitas aitem berkisar antara 0,335 0,574.Dengan demikian, seluruh aitem dari dimensi ini dikatakan valid karena sudah berada di atas nilai standar.Sedangkan,

untuk nilai reliabilitas didapatkan sebesar 0,832 . Nilai tersebut sudah berada di atas nilai standar 0,8 . Dengan demikian, dimensi ini dikatakan reliabel untuk remaja usia 15-21 tahun.

\section{Validitas dan Reliabilitas Dimensi Kecemasan Berkomitmen}

Tabel 5. Hasil pengujian validitas dan reliabilitas dimensi kecemasan berkomitmen

\begin{tabular}{cccc}
\hline No Aitem & Nilai Validitas & Nilai Reliabilitas & Keterangan \\
\hline 17 & 0,351 & 0,682 & Aitem valid namun tidak reliable \\
21 & 0,403 & 0,672 & Aitem valid namun tidak reliable \\
22 & 0,481 & 0,660 & Aitem valid namun tidak reliable \\
26 & 0,416 & 0,671 & Aitem valid namun tidak reliable \\
29 & $\mathbf{0 , 1 6 9}$ & 0,709 & Aitem tidak valid dan tidak reliable \\
30 & 0,316 & 0,688 & Aitem valid namun tidak reliable \\
32 & $\mathbf{0 , 2 0 1}$ & 0,707 & Aitem tidak valid namun tidak reliable \\
35 & 0,495 & 0,657 & Aitem valid namun tidak reliable \\
17 & 0,351 & 0,682 & Aitem valid namun tidak reliable \\
47 & 0,412 & 0,671 & Aitem valid namun tidak reliable
\end{tabular}

Berdasarkan tabel 5, dapat kita lihat bahwa nilai validitas dari dimensi kecemasan berkomitmen berkisar antara 0,169-0,495 dengan 2 aitem yang dinyatakan tidak valid, yakni pada nomor 29 dan 32. Hal ini dikarenakan nilai validitas kedua aitem tersebut berada dibawah 0,24 yakni 0,169 dan 0,201. Sedangkan, untuk nilai reliabilitas didapatkan sebesar 0,703 . Nilai tersebut berada di bawah 0,8 yang merupakan batas reliabilitas. Kesimpulan dari pengujian nilai validitas dan reliabilitas dimensi kecemasan berkomitmen adalah 2 aitem dari total keseluruhan 10 aitem dinyatakan tidak valid dan dimensi kecemasan berkomitmen dinyatakan tidak reliabel untuk remaja usia 15-21 tahun. 
Validitas dan Reliabilitas Dimensi Konflik Eksternal

Tabel 6. Hasil pengujian validitas dan reliabilitas dimensi konflik eksternal

\begin{tabular}{cccc}
\hline No. aitem & Nilai Validitas & Nilai Relibilitas & Keterangan \\
\hline 6 & 0,271 & 0,432 & Aitem dinyatakan valid namun tidak reliable \\
9 & 0,290 & 0,419 & Aitem dinyatakan valid namun tidak reliable \\
14 & 0,293 & 0,419 & Aitem dinyatakan valid namun tidak reliable \\
23 & 0,353 & 0,374 & Aitem dinyatakan valid namun tidak reliable \\
46 & $\mathbf{0 , 1 3 6}$ & 0,522 & Aitem dinyatakan tidak valid dan tidak reliable \\
\hline
\end{tabular}

Berdasarkan tabel 6, dapat kita lihat bahwa rentang nilai validitas dari dimensi konflik eksternal adalah 0,136-0,353 dengan 1 aitem dinyatakan tidak valid pada nomor 46. Dinyatakan tidak valid karena aitem tersebut berada di bawah nilai standar yakni hanya sebesar 0,136.Sedangkan, untuk pengujian reliabilitas didapatkan nilai sebesar 0,491. Nilai tersebut berada di bawah 0,8 . Kesimpulan dari pengujian validitas dan reliabilitas dimensi konflik eksternal adalah 1 aitem dari total keseluruhan 5 aitem dinyatakan tidak valid, dan dimensi konflik eksternal dinyatakan tidak reliabel untuk remaja usia 15-21 tahun

\section{Validitas dan Reliabilitas Alat Ukur IPK}

Tabel 7. Hasil pengujian validitas dan reliabilitas keseluruhan IPK

\begin{tabular}{ccc}
\hline Validitas & Reliabilitas & Keterangan \\
\hline $0,063-0,587$ & 0,893 & 6 aitem dinyatakan tidak valid \\
\hline
\end{tabular}

Berdsarkan tabel 7, dapat dilihat bahwa secara keseluruhan alat tes IPK memiliki rentang validitas dari 0,063-0,587 dengan 6 aitem yang gugur, yakni pada aitem 2, 6, 19, 24, 32, dan 46 dengan masing-masing nilai validitasnya $0.063 ; 0,235 ; 0,158$;

\section{DISKUSI}

Pengujian validitas dan reliabilitas IPK ke dalam bahasa Indonesia dengan mengganti kalimat yang awalnya mengacu pada bidang studi atau pekerjaan dengan jurusan perkuliahan ini menghasilkan hasil yang berbeda ketika dihitung validitas dan reliabilitas per dimensi dan ketika dihitung validitas dan reliabilitas keseluruhan.

Hasil pengujian skala konstruk dari IPK. Hasil yang didapatkan adalah tiga dari total keseluruhan 29 aitem yang diujikan dinyatakan tidak valid serta 15 aitem dari total keseluruhan 29 aitem yang diujikan dinyatakan tidak reliable untuk remaja kelas 12 .

Untuk dimensi kecemasan berkomitmen, berdasarkan hasil pengujian validitas dan reliabilitas menunjukkan
0,090; 0,160; dan 0,097. Sedangkan untuk reliabilitasnya sebesar 0,893 .Kesimpulan dari pengujian validitas dan reliabilitas keseluruhan IPK adalah 42 aitem dari total keseluruhan 48 aitem dinyatakan valid dan reliabel untuk remaja usia 15-21 tahun.

bahwa seluruh aitem tidak reliabel.Peneliti menduga, hal ini disebabkan jumlah aitem pada dimensi ini hanya 10 aitem.Sehingga ada baiknya dilakukan penambahan aitem. Untuk dimensi konflik ekternal, berdasarkan hasil pengujian validitas dan reliabilitas menunjukkan bahwa seluruh aitem dinyatakan tidak reliabel.Peneliti berasumsi hal ini dikarenakan jumlah aitem pada dimensi ini hanya 5 aitem.Sehingga ada baiknya untuk dimensi ini dilakukan penambahan aitem.

Namun, hasil berbeda didapatkan ketika peneliti melakukan uji validitas dan reliabilitas untuk keseluruhan aitem alat tes IPK.Hasil tersebut menyatakan bahwa 43 aitem dari total 48 aitem pada awalnya dinyatakan valid dan reliable untuk remaja kelas 12. 
Kedua perbandingan uji validitas dan reliabilitas di atas menunjukkan bahwa IPK yang telah dimodifikasi hanya valid dan reliabel jika diujikan secara keseluruhan, bukan berdasarkan dimensidimensi yang ada.

Tabel 8. Perbandingan penelitian sekarang dan penelitian sebelumnya

\begin{tabular}{lll}
\hline & $\begin{array}{l}\text { Pratomo } \\
(2012)\end{array}$ & $\begin{array}{l}\text { Penelitian } \\
\text { Sekarang }\end{array}$ \\
\hline Validitas & $0,310-0,674$ & $0,063-0,587$ \\
Reliabilitas & $0,940-0,942$ & $0,888-0,896$ \\
\hline
\end{tabular}

Berdasarkan tabel 8, dapat dilihat bahwa hasil penelitian saat ini lebih kecil dari penelitian sebelumnya. Dengan demikian, dapat dikatakan dalam penelitian ini tidak menunjukkan bahwa aitem-aitem yang diterjemahkan oleh Pratomo (2012) tidak bermasalah Hal tersebut dikarenakan sampel yang digunakan dalam penelitian cenderung homogen, karena subjek berkumpul di area cukup bermasalah dan bermasalah dengan presentase masingmasing sebesar $41 \%$ dan $44,16 \%$. Sampel yang homogen menyebabkan rendahnya sebaran hasil sehingga didapatkan hasil yang cenderung homogen. Menurut Erickson (2006), remaja adalah tahap seseorang memiliki masalah dalam kariernya mereka. Oleh karena itu, peneliti merasa perlunya penambahan partisipan dari segi rentang usia maupun jumlah kuota.

\section{SIMPULAN}

Hasil pengujian validitas dan reliabilitas dari IPK didapatkan 42 aitem dari total keseluruhan awal 48 aitem dinyatakan valid dan reliable untuk remaja kelas 15-21 tahun dengan rentang nilai validitas sebesar 0,063-0,587 dan rentang reliabilitas sebesar 0,893 .

Berdasarkan hasil pengujian validitas dan reliabilitas dimensi kebingungan pengambilan keputusan dari segi aitem maupun dimensi dinyatakan valid dan reliabel untuk remaja usia 15-21 tahun.

Berdasarkan hasil pengujian validitas dan reliabilitas dimensi kecemasan berkomitmen ditemukan bahwa 2 aitem dari total keseluruhan 10 aitem dinyatakan tidak valid, serta seluruh aitem dinyatakan tidak reliabel untuk remaja usia 15-21 tahun.

Berdasarkan hasil pengujian validitas dan reliabilitas konflik eksternal ditemukan bahwa 1 aitem dari total keseluruhan 5 aitem dinyatakan tidak valid dan seluruh aitem dinyatakan tidak reliabel untuk remaja usia 15-21 tahun.

Kesimpulan akhir dari penelitian ini adalah sebayak 42 aitem IPK yang telah dimodifikasi telah valid dan reliabel. Namun, jika dibandingkan dengan penelitian sebelumnya nilai validitas dan reliabilitas tidak lebih besar dari penelitian yang telah dilakukan oleh Pratomo (2012).Sehingga, penelitian tidak terbukti bahwa aitem yang telah diterjemahkan oleh Pratomo (2012) bermasalah.Empat puluh dua aitem yang telah valid dan reliabel ini hanya dapat digunakan secara keseluruhan. Hal ini dikarenakan dalam perhitungan uji validitas dan reliabilitas perdimensi ditemukan banyak aitem yang tidak reliabel bagi remaja usia 15-21 tahun yang disebabkan adanya kesalahan dalam teknik pengambilan sampel.

\section{SARAN}

Melihat masih adanya kelemahan dalam penelitian yang dilakukan, peneliti mencoba memberikan saran untuk penelitian selanjutnya. Adapun saran yang diberikan untuk penelitian berikutnya dari segi teknik sampling, pengujian validitas dan reliabilitas, serta rentang usia partisipan.

Untuk penelitian selanjutnya disarankan untuk menggunakan teknik random sampling, hal ini untuk memperkecil kemungkinan adanya homogenitas dari partisipan.Homogenitas yang dimaksud adalah homogenitas dari segi respon dari partisipan.Dilihat dari gambaran subjek, dapat dilihat bahwa sebagian besar subjek berada di area cukup bermasalah dan bermasalah. 
Menurut Erickson (dalam Sharf, 2006) remaja memang memiliki konflik yang berkaitan dengan diri, salah satunya mengenai karier. Oleh sebab itu, peneliti merasa untuk penelitian selanjutnya perlu dilakukan perluasan rentang usia partisipan dan jumlah partisipan. Hal ini diperlukan untuk meningkatkan nilai reliabilitas dari IPK.

Jika peneliti berikutnya ingin melakukan uji validitas, disarankan untuk mengikutsertakan penilaian ahli (expert judgement) dan melakukan uji konstruk dengan membandingkan alat tes IPK dengan alat tes lain yang mengukur konstruk yang kurang lebih sama. Untuk pengujian reliabilitas mungkin diperlukan uji reliabilitas tes ulang, dengan pengambilan data sebelum individu membuat keputusan dan setelah individu mengambil keputusan.Sehingga, diharapkan alat test IPK dapat menjadi reliabel.

Hal lain yang perlu diperhatikan dalam pengujian validitas dan reliabilitas tes IPK adalah melakukan penambahan aitem pada dimensi IPK, khususnya dimensi yang dinyatakan tidak reliabel. Dengan melakukan penambahan aitem, diharapkan nilai reliabilitas dari dimensi tersebut menjadi lebih baik bahkan reliabel.

\section{DAFTAR PUSTAKA}

Amelia \& Gunawan (2015). Deteksi kegagalan pemrosesan informasi kognitif pada remaja. Jurnal Noetic Psychology, 4(2), 130-148.

Azwar, S. (2009). Reliabilitas dan validitas (cetakan ketiga). Yogyakarta: Pustaka Belajar.

Azwar, S. (2010). Reliabilitas dan Validitas. Yogyakarta: Pustaka Belajar.

Azwar, S. (2012). Penyusunan skala psikologi (edisi kedua). Yogyakarta: Pustaka Belajar
Brown, D. \& Brooks, L. (1996).Career choice \& development (3rd ed.). San Fransisco, California

Ghozali, I. (2011). Aplikasi analisis multivariate dengan program IBM SPSS 19. Semarang: Badan Penerbit Universitas Diponegoro.

Gunawan, W (2013). Pengaruh sumbersumber efikasi diri dan efikasi diri pengambilan

keputusan karier terhadap adaptabilitas karier remaja (Tesis tidak dipublikasikan).

Universitas Indonesia, Jakarta.

Osterlind, S.J. (2002). Constructing test items: Multiple-choice, constructed-response, performance, and other formats (2nd ed.). New York: Kluwer Academic Publisher

Pratomo, J \& Gunawan, W. (2012). Uji validitas dan reliabilitas career thought inventory Jurnal Noetic Psychology, 2(1), 40-56.

Sampson, J. P., Peterson, G. W., Lenz, J. G., Reardon, R. C., \& Saunders, D. E. (1996). Career thought Inventory professional manual (2005). Florida Aveneu: Lutz

Sarwono, J. (2011). Buku pintar ibm spss statistic 19: Cara operasi, prosedur analisa data,dan interpretasi. Jakarta: PT Elex Media Komputindo

Sharf, R.S. (2006). Applying Career Development Theory to Counseling. USA: University of

Delaware

Singleton, R.A. \& Straits, B.C. (1999).Approaches to social research (3rded.). New York: Oxford University Press

Sukardi. (2003). Metodologi penelitian pendidikan: Kompetensi dan praktiknya. Jakarta: Bumi Aksara

Sirodjuddin, A. (2008) SMK lebih menjanjikan masa depan dibanding SMA [WEB log post]. Retrieved from http://ardansirodjuddin.wordpress.com/2 008/06/03/smk-lebihmenjanjikan-masadepan-di-banding-sma/ 